\title{
A Survey of Listening Comprehension Strategies Used by Students of English Major
}

\author{
Zhaoqin Yu \\ School of Foreign Languages, Hubei University of Chinese Medicine, Wuhan Hubei, 430065, China
}

Keywords: Students of English majors, Listening comprehension, Listening strategies.

\begin{abstract}
According to O'Malley \& Charmot's definition of learning strategy content, this paper investigates the use of listening strategies of college English majors in listening comprehension by questionnaire. The study found that learners' use of listening strategies is not sufficient, especially the lack of use of social affective strategies and metacognitive strategies. At the same time, the use of cognitive strategies is not balanced and more learners use translation strategies in listening comprehension, Prediction and inference strategies, and less to use self-questioning strategies. According to the survey results, the author puts forward some suggestions on the strategy teaching in English majors' listening teaching.
\end{abstract}

\section{Introduction}

Rivers Wilga. M, a professor of linguistics at Harvard University (1981), states in his Teaching Foreign Language Skills that listening in one day is about twice what it says, four to five times more reading and writing. This shows that in daily communication, the position of hearing is very important. English listening as an important way for learners to gain comprehensible input is an important basic skill that English majors must master. At the same time, it is also significant to improve learners' abilities to apply language comprehensively.

Although as early as the 90s of last century, domestic and foreign scholars began to study and comment on the process of listening comprehension from different perspectives, but so far our mysterious process is still very little understood. Vandergrift (2007) proposed that the listening comprehension process is an invisible perceptual process, so it is not easy to conduct direct observations. Learning strategy is the learner in order to improve the learning efficiency and learning efficiency, purposeful and conscious development of a complex program of learning process. Listening strategies are part of the learning strategy. In the 1990s, O'Malley \& Charmot (1990) divided learning strategies into cognitive strategies, social emotional strategies and metacognitive strategies based on previous theoretical studies. In terms of listening learning, cognitive strategies mainly include translation strategies, application of knowledge prediction and inference strategies, note-taking strategies and self-questioning strategies. Social affective strategies mainly include cooperative learning strategies, self-confidence and interest in learning. Cognition includes strategies such as setting learning objectives, self-reflection and evaluation, and self-learning after class.

Although the hearing process is difficult to observe, the strategies learners use in the process of hearing can be found through investigation. The purpose of this study is to find out the problems and shortcomings in listening teaching by investigating the use of listening strategies of English majors in colleges and universities and to put forward some countermeasures for teaching strategies.

\section{Study Description}

\subsection{Study methods}

The subjects of this study were students majoring in English at the level of 2016 and 2017 in college. These students have 2 hours of listening class per week for a total of 210 people. To understand the use of listening strategies, the author conducted a questionnaire survey. The 
questionnaire had already been tested Cronbach's reliability coefficient in the previous period, with an Alpha value of 0.802, indicating that the reliability of the questionnaire was good. The KMO value was 0.74 , and the Bartlett's P value was less than 0.05 , indicating that factor analysis was effective. The questionnaire is divided into two parts. The first part is about the basic information of the respondent, including gender, age and time of English learning. The second part is composed of 30 questions, which are designed to investigate the relationship between cognitive strategies, social emotion Strategy and metacognitive strategy usage, each set of 10 strategies for each problem. The alternatives for each question are: always, mostly, half, and occasionally, never. Options score from high to low for 5 points, 4 points, 3 points, 2 points, 1 point. Finally, the total score of the questionnaire data, the average score, the percentage of statistics and description.

\section{Survey result}

The overall score of the questionnaire results as shown below:

\begin{tabular}{|c|c|c|c|c|}
\hline Category & Number of people & Maximum score & Minimum score & Average value \\
\hline cognitive strategy & 210 & 5 & 1 & 3.49 \\
\hline $\begin{array}{c}\text { social emotion } \\
\text { strategy }\end{array}$ & 210 & 4 & 1 & 2.45 \\
\hline $\begin{array}{c}\text { metacognitive } \\
\text { strategy }\end{array}$ & 210 & 4 & 1 & 2.38 \\
\hline Total & 210 & 5 & 1 & 2.77 \\
\hline
\end{tabular}

It can be seen from the table above that the average value of cognitive strategies is the highest, indicating that students use most cognitive strategies in listening comprehension, followed by social affective strategies and the least used metacognitive strategies. From an overall averages, students' use of listening strategies is not enough.

The author also conducted a percentage of statistics on the frequency of use of each strategy, the statistical results as shown below:

Table 1 Cognitive strategies use frequency table

\begin{tabular}{|c|c|c|c|c|c|}
\hline Strategy name & always(\%) & most(\%) & half(\%) & occasionally(\%) & never(\%) \\
\hline $\begin{array}{c}\text { translation } \\
\text { strategy }\end{array}$ & $46 \%$ & $31 \%$ & $14 \%$ & $9 \%$ & 0 \\
\hline $\begin{array}{c}\text { inference and } \\
\text { prediction } \\
\text { strategies }\end{array}$ & $32 \%$ & $25 \%$ & $18 \%$ & $15 \%$ & $10 \%$ \\
\hline $\begin{array}{c}\text { noting } \\
\text { strategy }\end{array}$ & $26 \%$ & $20 \%$ & $26 \%$ & $18 \%$ & $10 \%$ \\
\hline $\begin{array}{c}\text { background } \\
\text { and resource } \\
\text { strategy }\end{array}$ & $29 \%$ & $23 \%$ & $25 \%$ & $15 \%$ & $8 \%$ \\
\hline $\begin{array}{c}\text { self-questioni } \\
\text { ng strategy }\end{array}$ & $15 \%$ & $17 \%$ & $22 \%$ & $25 \%$ & $21 \%$ \\
\hline
\end{tabular}


Table 2 Social emotional strategies use frequency table

\begin{tabular}{|c|c|c|c|c|c|}
\hline Strategy name & always(\%) & most(\%) & half(\%) & occasionally(\%) & never(\%) \\
\hline $\begin{array}{c}\text { reduce anxiety } \\
\text { strategy }\end{array}$ & $19 \%$ & $20 \%$ & $23 \%$ & $26 \%$ & $12 \%$ \\
\hline $\begin{array}{c}\text { develop } \\
\text { learning interest } \\
\text { strategy }\end{array}$ & $27 \%$ & $23 \%$ & $23 \%$ & $16 \%$ & $11 \%$ \\
\hline $\begin{array}{c}\text { enhance } \\
\text { self-confidence } \\
\text { strategy }\end{array}$ & $20 \%$ & $28 \%$ & $22 \%$ & $28 \%$ & $2 \%$ \\
\hline $\begin{array}{c}\text { cooperative } \\
\text { learning }\end{array}$ & $12 \%$ & $16 \%$ & $18 \%$ & $43 \%$ & $11 \%$ \\
\hline
\end{tabular}

Table 3 Metacognitive strategies use frequency tables

\begin{tabular}{|c|c|c|c|c|c|}
\hline Strategy name & always(\%) & $\operatorname{most}(\%)$ & $\operatorname{half(\% )}$ & $\begin{array}{c}\text { occasionally( } \\
\%)\end{array}$ & never(\%) \\
\hline self-monitoring strategy & $33 \%$ & $30 \%$ & $27 \%$ & $10 \%$ & 0 \\
\hline $\begin{array}{c}\text { self-reflection and } \\
\text { evaluation strategy }\end{array}$ & $16 \%$ & $17 \%$ & $18 \%$ & $45 \%$ & $4 \%$ \\
\hline $\begin{array}{c}\text { develop learning plan } \\
\text { strategy }\end{array}$ & $21 \%$ & $31 \%$ & $32 \%$ & $13 \%$ & $3 \%$ \\
\hline $\begin{array}{c}\text { after-school self-learning } \\
\text { strategy }\end{array}$ & $22 \%$ & $28 \%$ & $25 \%$ & $23 \%$ & $2 \%$ \\
\hline
\end{tabular}

Thus, students use the most frequent translation strategies in cognitive strategies, followed by background and resource strategies, inference and prediction strategies, and note-taking strategies, while students use self-questioning strategies with the lowest frequency. Reducing anxiety and increasing self-confidence in social affective strategies are used more frequently and the use of cooperative learning strategies is extremely scarce. In the use of metacognitive strategies, self-monitoring strategies are most frequently used, especially in the process of hearing can remind myself to keep a high degree of concentration; followed by the development of learning plans and after-school self-learning, self-reflection and evaluation strategies are used Less, fewer students take the initiative to sum up the reasons do not understand, can not correctly assess their current level of listening and ability.

\section{Inspiration to Strategy Teaching in Listening Teaching}

\subsection{Develop students' awareness of listening strategies}

Listening strategy is a major element of listening comprehension. Being able to use listening strategies flexibly is also one of the goals of listening comprehension. For English majors, teachers should start from the younger age to develop their awareness of the use of listening strategies and help students develop the proper use of strategies. In the process of teaching, teachers not only play materials for students to practice, but should teach students how to practice, how to purposefully and consciously choose different strategies to listen to, and encourage students to use listening strategies for listening training. Teachers can explain to students the importance of using the strategy by analyzing the different hearing effects of not using the strategy and using the strategy. In addition, teachers should demonstrate how to apply specific strategies, such as summarizing the news, while requiring students to be familiar with the structure of English news Seize the news lead part, on the other hand can also demonstrate how to summarize the news by self-questioning (What happened in 
the news? Who got involved? When and where?). The survey found that students' use of specific listening strategies was uneven and some of them were rarely used, but these less frequently used strategies were often the most effective and teachers should help students recognize this and reinforce these strategies in teaching Training and use.

\subsection{Develop students' use of social affective strategies}

Emotion is the booster that keeps learning motivation. However, many listening classes do not pay enough attention to emotion. Students complain that there is a lot of stress and anxiety in the classroom. The author believes that teachers can improve from the following aspects: First, to help students put a positive attitude, to make students aware of the hearing process of hearing the information gap is unavoidable, reducing their anxiety levels; secondly, to actively create a relaxed atmosphere of learning to relax Student pressure, the author tried to invite students to make News Report before class, students choose the most interesting news heard the past week and classmates to share with students who can take the initiative to give some incentives, this approach can be active in the classroom atmosphere , To mobilize students' interest; Finally, to strengthen cooperative learning, teachers encourage students to group discussions in class, but also in the form of group after class for listening training, the author has taught classes require students to group after the form of digital Listen to note, many students responded well.

\subsection{Strengthen metacognitive strategy training}

Metacognition is cognitive cognition, many scholars believe that the status of metacognitive strategy is slightly higher than the other two learning strategies. "To teach people to fish than to teach people to teach" in the training of metacognitive strategies, students develop their own listening comprehension goals, effectively self-monitoring in the learning process, to reflect on their own problems in the process of listening learning, to further clarify The direction of hard work is conducive to improving students 'ability to learn independently, and truly improve learners' listening ability.

\section{Conclusions}

Listening is a complex process of understanding and is also a positive thinking process. Therefore, to obtain a good hearing effect, the requirements of the listener are very high. Not only English language knowledge but also good psychological qualities and relevant knowledge Background, but also need a higher ability to use listening strategies. Based on the survey results, this article puts forward some suggestions to English majors' listening teaching. The author believes that listening strategies are attainable. Listening teachers should strengthen their strategies training in teaching so that they can master these listening skills and let them exert their value so that students can truly become the director of learning.

\section{Acknowledgement}

This essay is a research paper of "Research on the Relationship between Metacognitive Learning Strategy and English Listening" at the level of teaching reform in Hubei University of Traditional Chinese Medicine.

\section{References}

[1] Rivers Wilga. M Teaching Foreign Language Skills, Chicago: University of Chicago Press, 1981.

[2] Vandergrift L. Recent Development in Second \& Foreign Language Listening Comprehension Research, Language Teaching, 2007, (3).

[3] Anna Charmot, J. Michael O'Malley Language development through Content. Mathematics Teacher's guide, Reading, Mass. : Addison-Wesley, 1990. 
[4] Anna Charmot, J. Michael O'Malley LearningStrategies in Second Language Acquisition, Cambridge University Press, 1990.

[5] Zhang Beizhen. Analysis of the Current Research on Second Language Listening Comprehension at Home and Abroad, Contemporary Foreign Language Studies, 2012(10):42-45.

[6] He Kaida, Li Lijun. A Survey on the Use of Listening Strategies with English Majors, Neijiang Technology. 2016 (11):64-65.

[7] Wu Yan, Zhang Huiling. Investigation and Analysis of Listening Class Teaching Efficiency in English Majors, Journal of Xi'an International Studies University. 2005(12):28-30.

[8] Wang Wei. Listening and hearing impairment in English listening comprehension, Journal of PLA University of Foreign Languages. 1991(1):27-35.

[9] Wu Jianqiang. Causes of English Listening Disorder and Countermeasures, English audio-visual education programme. 2005(4):53-55. 